\title{
Crossing the Tasman: Determinants of Price Discovery for Australia-New Zealand Cross-listed shares
}

\author{
Bart Frijns, Aaron Gilbert*, Alireza Tourani-Rad \\ Department of Finance, Auckland University of Technology and Auckland Centre for \\ Financial Research
}

This Version: May 2013

* Corresponding Author. Aaron Gilbert, Department of Finance, Auckland University of Technology, Private Bag 92006, 1020 Auckland, New Zealand, Email: agilbert@aut.ac.nz, phone: +649921 5713, Fax: +6499219940.

Crossing the Tasman: Determinants of Price Discovery for Australia-New Zealand Cross-listed shares 


\begin{abstract}
Price discovery is the process by which markets incorporate new information. In this study, we investigate the price discovery for 19 stocks cross-listed on the NZX and the ASX between 1998 and 2012. We observe strong downward trends in the contribution to price discovery of the NZX, both for New Zealand firms cross-listing on the ASX, and Australian firms cross-listing on the NZX. This suggests that the competitiveness of the NZX relative to the ASX is decreasing. Towards the end of the sample period, $50 \%$ of the price discovery for New Zealand firms takes place on the ASX, and the NZX acts as a satellite market for Australian firms. We further examine the driving factors behind this decline, such as spreads, and trading and quoting activity.
\end{abstract}

Key Words: Price Discovery; Market Microstructure. 


\section{Introduction}

Recent advances in information technology and globalisation have given companies the opportunity to list their shares on multiple exchanges. Generally, companies choose those exchanges that will provide better listing conditions, greater access to capital, improved analyst following and that will broaden their investor base. However, at the same time, investors are gaining increasing access to multiple exchanges, and are no longer restricted to trading only in their home market. Because of this possibility for firms to choose where to list their shares, and because of the possibility for investors to choose where to trade shares, the competition between exchanges for order flow has increased, and exchanges need to be competitive and remain liquid and efficient to remain attractive for both companies and investors. ${ }^{1}$

One way of measuring the relative competitiveness of exchanges is through price discovery. Price discovery is the process by which new information gets impounded into stock prices and forms a crucial function of an exchange. When a security is listed on multiple exchanges, price discovery addresses the question of where information gets impounded most efficiently. When an exchange dominates in terms of price discovery, it suggests that this is the exchange where traders prefer to execute their trade. The importance of price discovery can be highlighted by a quote by the TSX Board of Governors: "The TSE cannot afford to have the U.S. markets become the price discovery mechanism for Canadian inter-listed stocks" (Eun and Sabherwahl, $2003 \mathrm{pg}$ 550). Given the importance of price discovery for the competitiveness of exchanges, an important question becomes what drives price discovery. Harris et al. (2002) argues that informed traders, whose trading activity impounds new

\footnotetext{
${ }^{1}$ An example of the increased openness of global capital markets it the recent move of Cavotech from the NZX to the OMX Stockholm. The CEO argued it was to "help see it raise capital, improve liquidity and increase the share price." (Wood, 2011).
} 
information into prices, are attracted to exchanges based on market factors like the depth, immediacy and quoted spreads that they can offer to traders. Therefore, the location in which new information gets incorporated into prices should be driven by the relative efficiency of the exchanges in question.

In this study, we examine the contribution to price discovery for two highly integrated markets, the Australian Stock Exchange (ASX) and the New Zealand Stock Exchange (NZX). We collect data for 11 New Zealand firms cross-listed on the ASX and 8 Australian firms cross-listed on the NZX, for a period of 14 years, 1998-2012. To examine price discovery, we estimate both the Gonzalo and Granger (1995) Component Share (CS), and the Hasbrouck (1995) Information Share (IS) for each year of our sample. Over all firm-years, we find that the home market dominates in terms of price discovery, which is consistent with prior literature. However, when we examine price discovery year-by-year, we observe a clear downward trend in the NZX's contribution to price discovery. For New Zealand firms this decline goes from about $90 \%$ in 1998 to about 50\% in 2012. For Australian firms the decline goes from about $35 \%$ to $15 \%$, suggesting that for Australian firms the NZX is almost a pure satellite market. When we examine the determinants of price discovery, we find a strong relationship between relative trades, volume and spread for New Zealand firms. For Australian firms, relative spread and volume seem to be important determinants.

This paper extends the work of Frijns et al. (2010), by considering a substantially longer period from 1998 to 2012, and the work of Eun and Sabherwal (2003) by considering bidirectional cross-listing (i.e. listing of New Zealand firms on the ASX and vice versa). The combination of these two extensions allows us to determine whether there are differences in 
the factors driving price discovery. Very few studies have considered such bi-directional settings.

The rest of the paper set out as follows. Section 2 discusses the extant literature on price discovery. Section 3 discusses the methodologies employed in this paper. Section 4 outlines the data employed and provides a summary of the data. Section 5 presents our empirical findings and Section 6 provides conclusions.

\section{Literature Review}

Price discovery is a key function of a financial market (Eun and Sabherwal, 2003). A general observation is that price discovery should mostly occur in the home market (Bacidore and Sofianos, 2002), as this is the market in which information about the company is mostly created. This notion assumes investors will trade on that information in the home market, but as investors in highly integrated markets have the ability to trade in what they consider to be the best exchange, where information gets impounded into prices becomes uncertain. If investors prefer to trade in the more "efficient" market, then a cheaper and more liquid foreign market could also become the informationally dominant market.

There is a growing literature examining the issue of price discovery in a number of settings, particularly looking at the price discovery of stocks listed on multiple exchanges. Initially, studies examined the relative importance of exchanges within the US, particularly between the NYSE and regional exchanges (Harris et al., 1995; Hasbrouck, 1995). An interesting extension is Harris et al. (2002), who looked at the relative contributions to price discovery for the NYSE and regional exchanges at three points in time; 1988, 1992 and 1995. They find that price discovery contributions change over time, particularly in relation to changes in the 
competitive position of the various exchanges against each other. They note that as the NYSE became relatively more expensive with regards to transaction costs in around 1992, price discovery migrated to the regional exchanges. In 1995, once NYSE spreads had reduced, the NYSE regained some of its contribution to price discovery.

A number of studies also examine the location of price discovery for internationally crosslisted firms, addressing the question of which is the informationally dominant market, the home or the foreign market. Despite the assertions of Bacidore and Sofianos (2002) that the home market should dominate the price discovery, empirical evidence is mixed. For instance, Lieberman et al. (1999) examine price discovery for six Israeli firms cross-listed on the NYSE and find only a limited informational role for the NYSE for five of the firms. Su and Chong (2007) look at eight Chinese firms listed on both the Hong Kong Stock Exchange and the NYSE and also find a limited informational role for the US exchange. Likewise, Ding et al. (1999) examine a Malaysian firm cross-listed on the Singapore Exchange and find that the Malaysian market is largely the dominant one. Lok and Kalev (2006) and Frijns et al. (2010), both study bi-directional listings between the Australian and New Zealand Stock Exchanges, and find that the home market dominates but that the foreign market has a small but significant role in price discovery.

However, several studies have found that the foreign market plays an important role in price discovery. Kadapakkam et al. (2003) in a study of Indian companies listed on the London Stock Exchange, find that both markets contribute equally to price discovery. Hupperts and Menkveld (2002), looking at Dutch firms cross-listed on the NYSE, find wide variations on a per company basis, with some finds being dominated by price discovery in the home market, some by the foreign market, and others by both markets. 
Eun and Sabherwal (2003) examine price discovery for Toronto Stock Exchange stocks cross-listed on US exchanges for a six-month period in 1998. As with the findings in Hupperts and Menkveld (2002), Eun and Sabherwal (2003) show wide variation in the contribution to price discovery of the US exchanges, averaging $38.1 \%$ but ranging from $0.2 \%$ to $98.2 \%$. They note that while the home market dominates in many cases, there are a number of companies for which price discovery is dominated by the US exchange, making the TSX a mere satellite. They further examine the determinants of price discovery and find that price discovery is driven by the proportion of information-based trades occurring in the US. Lieberman et al. (1999) and Hasbrouck (1995) also show that the bid-ask spread ratio affects the level of price discovery.

One weakness of the studies on price discovery to date, particularly in relation to measuring the effects of exchange competition on the future of smaller exchanges, is that most of the studies are snapshots in time, focusing on measuring price discovery in one relatively short period of time, typically less than a year. As such, changes over time in price discovery, and what may cause these shifts, have not really been examined in the literature. One study that does look at the development of price discovery over time is Frijns et al. (2010). They examine both New Zealand firms listed on the ASX and Australian firms listed on the NZX for the period 2002-2007. Frijns et al. (2010) show that while the home market is dominant for both New Zealand firms listed on the ASX and Australian firms listed on the NZX, the ASX was increasing its share of price discovery over time for both groups. This suggests that the NZX is increasingly becoming less relevant for Australia-New Zealand cross-listed firms.

\section{Methodology}


To study the informational role of the NZX and ASX markets for New Zealand and Australian cross-listed firms, we investigate the contribution to price discovery of each market. To assess this, we follow the literature by estimating vector error correction model (VECM) and computing price discovery measures from these model estimates.

Consider a single security that is listed on two exchanges (NZX and ASX). Let $p_{j t}^{N Z X}$ be the $\log \mathrm{NZ}$ dollar price of security $j$ traded on the NZX, and let $p_{j t}^{A S X}$ be the log New Zealand dollar price of the asset traded on the ASX. If the two assets are identical and completely fungible, then arbitrage implies that the price difference $\left(p_{j t}^{N Z X}-p_{j t}^{A S X}\right)$ is bounded with

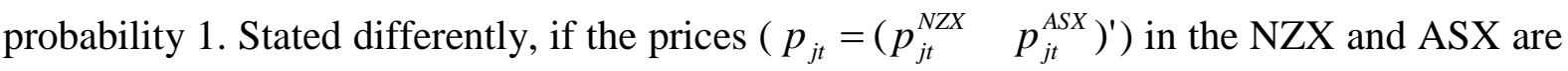
for the same asset then prices will be cointegrated, with cointegrating vector $\beta_{j}{ }^{\prime}=\left(\begin{array}{ll}1 & -1\end{array}\right)$. Cointegration of these assets implies that price changes can be expressed as a VECM of the form,

$$
\Delta p_{j t}=c_{j}+\alpha_{j} \beta_{j}^{\prime} p_{j t}+\sum_{i=1}^{I} \Gamma_{i j} \Delta p_{j t-i}+\varepsilon_{j t},
$$

where $\alpha_{j}$ is the $(2 \times 1)$ vector of containing the speed of adjustment coefficients for NZ prices and Australian prices and $\Gamma_{i j}$ are $(2 \times 2)$ matrices containing coefficients on lagged price changes. Note that the specification of the cointegrating vector $\beta^{\prime}$ implies that we expect the first element of $\alpha, \alpha^{N Z X} \leq 0$ and the second element of $\alpha, \alpha^{A S X} \geq 0$.

We obtain our price discovery measure using the VECM stated in Equation (1) in two ways. The first method is the permanent-transitory (PT) decomposition of Gonzalo and Granger 
(1995), which is commonly referred to as the Component Shares (CS). The second method is commonly referred to as the Information Shares (IS) due to Hasbrouck (1995).

\subsection{Gonzalo and Granger (1995) Component Shares}

The Gonzalo and Granger (1995) PT decomposition compares the speed of adjustment coefficients of the two markets. The lower the speed of adjustment coefficient, the more informative that market is. For example, if the NZX is completely dominant in terms for price discovery and the ASX is a pure satellite market, then $\alpha^{N Z X}=0$ and $\alpha^{A S X}>0$. Vice versa, if the ASX is completely dominant and the NZX is a pure satellite, then $\left|\alpha^{N Z X}\right|>0$ and $\alpha^{A S X}=0$. If neither market is completely dominant $\left|\alpha^{N Z X}\right|$ and $\alpha^{A S X}$ will both be positive, but their relative magnitudes will give us an indication of the degree of dominance over the other market. The CS can therefore be defined as

$$
C S_{j}^{A S X}=\frac{\left|\alpha_{j}^{N Z X}\right|}{\left|\alpha_{j}^{N Z X}\right|+\alpha_{j}^{A S X}},
$$

where $C S_{j}^{A S X}$ is the component share for a security on the ASX. Likewise, $C S_{j}^{N Z X}=1-C S_{j}^{A S X}$ is the component share for a security on the NZX.

\subsection{Hasbrouck (1995) Information Shares}

Whereas the CS only considers the speed of adjustment coefficient, the IS makes a different decomposition of the VECM. Hasbrouck's (1995) measure builds on the fact that if prices are cointegrated, they share a single common trend often referred to as the efficient price or underlying price of the assets. This efficient price is assumed to follow a random walk and the innovations in the efficient price are due to the arrival of new information. The total 
variance of the random walk is therefore a measure of the amount of information arriving to the market. The IS decomposes this variance and computes the percentage contribution of each market to the total variance of the common trend (efficient price). The higher the IS, the more informative the market is about the true price process.

\section{Data}

In this study, we consider the relative level of price discovery for both New Zealand firms cross-listed on the ASX and Australian firms cross-listed on the NZX. We examine price discovery for both types of firms over the period 1998-2012. However, we restrict our analysis to those firms that were cross-listed between the two exchanges prior to 2006have reliable results on possible movements of price discovery across the two markets. This restriction also ensures that there will be sufficient per year observations for each firm. We also require that intra-day data to be available for each firm from Thompson Reuters Tick History. As a result, our sample contains 11 New Zealand companies that are cross-listed on the ASX, and 8 Australian firms listed on the NZX. Appendix A provides an overview of the 19 firms used in this study.

We collect intra-day data on trade, bid and ask price, and number of trades, quotes and traded volume at a one minute frequency for the period 1 January 1998 to 31 December 2012. We also collect one-minute data bid and ask quotes on the NZD/AUD exchange rate. As price discovery is examined when both markets are open, we only utilise data for the overlapping trading hours of the two exchanges. The NZX opens at 10am and closes at 5pm NZ Time while the ASX opens at 10am and closes at 4pm AEST. For most days in the year there is a two hour time difference between NZ and AEST resulting in 5 hours of overlapping 
operations, although this can vary between 4 and 6 hours depending on the start and end dates for daylight savings between the two countries. We also restrict our analysis to days when both markets are open.

\section{Results}

\subsection{Summary Statistics}

Table 1 presents summary statistics for our sample for the NZX and ASX. Panel A and B report summary statistics for New Zealand and Australian firms, respectively. From Panel A, we observe that for most firms the majority of the trading and quoting activity occurs on the NZX, but there is considerable variation per firm. For instance, the ratio of NZX/ASX daily trades is on average close to 5, but varies from 12 (AIA and WHS) to 0.5 (FBU and TEL). For quoting activity, we observe an 8 times greater quoting activity on the NZX than the ASX, with again wide variation from 15.33 (AIA) to 1.16 (TEL). Likewise, $83.5 \%$ of the volume traded per day occurs on the NZX. Finally, spreads are also considerably lower on the NZX, on average $0.95 \%$ compared with $3.49 \%$ on the ASX.

Panel B, which looks at the Australian companies cross-listed on the NZX, also shows that most trading and quoting activity takes place in the home market. On average, we observe more than 2000 trades per day on the ASX, but just 287 on the NZX, and $92 \%$ of the volume traded occurs on the ASX. Spreads are also considerably lower, $0.97 \%$ for the ASX compared with $2.99 \%$ on the NZX. Overall, the results suggest that the home market remains the most important market for cross-listed firms in terms of trading and quoting activity. 
Table 2 presents summary statistics for each year for New Zealand (Panel A) and Australian (Panel B) firms. For New Zealand firms, we observe that over time more trade is occurring on the ASX, especially from 2009 onwards (in terms of Daily Trades and Daily Volume). This suggests that the ASX is increasingly becoming a more important market for New Zealand firms in terms of trades. However, relative quoting activity and relative bid-ask spreads remain relatively stable over time. The results for the Australian firms (Panel B) also suggest the NZX is becoming less important. This holds for relative Daily Trades, Daily Volume and Bid-Ask Spread. Only relative Daily Quotes do not change over time.

\subsection{Price Discovery}

One confounding factor in these summary statistics is the issue that firms enter the sample at irregular periods which may affect the statistics reported. Also, trading and quoting location are only some factors that affect competition between exchanges. As such, we next compute our two measures of price discovery, the Gonzalo Granger CS and the Hasbrouck (1995) IS.

In Table 3, we present the average price discovery measures per firm for New Zealand (Panel A) and Australian firms (Panel B). Overall, our results show that the home market is the informationally dominant market, which is consistent with most prior literature. For New Zealand firms, we observe that the NZX provides about $69 \%$ of price discovery for the 11 firms over our sample period, using both the CS and IS measures. We observe that price 
discovery ranges from around $55 \%-57 \%$ (TEL) to $84 \%-85 \%$ (WHS) ${ }^{2}$, showing that there is some variation in price discovery across the sample of New Zealand firms.

Panel B shows the price discovery measures for the Australian firms. On average, the ASX has between $78.6 \%$ (CS) and $81 \%$ (IS) of the price discovery of the Australian firms, suggesting that the ASX is informationally dominant over the NZX on average. As with the New Zealand firms there is some variation across firms. Lion Nathan has about $37-48 \%$ of price discovery occurring in the NZX. This may be explained by the fact that it was formed as an amalgamation of both Australian and New Zealand breweries and retains a significant manufacturing presence in New Zealand, which may explain the substantial price discovery occurring on the NZX, before its eventual delisting from both markets as a result of a takeover.

Comparing the respective roles of the foreign markets in Panels A and B supports the earlier summary statistics findings reported in Table 1. For New Zealand firms, we observe that the ASX plays a relatively greater role (around 30\%) in the price discovery than the NZX plays for Australian firms (around 20\%). However, both foreign markets contribute to price discovery of these dually listed firms.

\footnotetext{
${ }^{2}$ The Warehouse Group de-listed from the ASX in 2012, suggesting that they saw little value in a continued listing.
} 
We next examine the price discovery over time. Figures 1 presents the average NZX price discovery contribution for New Zealand and Australian firms per year. Panel A presents the average Information Share per year, while Panel B presents the average Component Shares per year. Although we observe some fluctuations in price discovery on a year-by-year basis, there is also a very clear trend in price discovery. For New Zealand firms (right scale) we observe a decrease in price discovery from over $90 \%$ to around $50 \%$ in both graphs. This indicates a marked decline in the contribution of the NZX to the price discovery of crosslisted New Zealand firms, and a marked increase in the importance of the ASX. The graphs demonstrate a similar pattern for the Australian firms (left scale). Australian firms demonstrate a marked decline in price discovery occurring on the NZX going from around $35 \%$ to around $15 \%$. This indicates that the NZX has become less important for Australian firms.

It is possible that the trends in Figure 1 are driven by the inclusion and removal of firms. In Table 4, we therefore present the New Zealand CS values by firm for each year. While there is some variation between years, the declining importance of the NZX remains apparent. For the New Zealand firms (Panel A), we observe a reduction in the contribution of the NZX to the price discovery for all firms but one firm (AIR). In seven of these cases, the decline is at least $10 \%$ over the 15 year period of our study. Furthermore, by 2012 we observe that for three firms (AIA, FBU, and TEL) the ASX is the informationally dominant market. In the case of TEL, less than $10 \%$ of the price discovery is occurring on the NZX.

We observe a similar pattern in the New Zealand CS values for the Australian firms (Panel B). With the exception of PPP, all firms experience a reduction in the contribution of the 
NZX to price discovery, and only PPP has a component share exceeding $10 \%$. This indicates that for Australian firms cross-listed on the NZX, the NZX has lost its relevance for in terms of price discovery.

The apparent decline in the relevance of the NZX is concerning. As discussed above, price discovery offers a relatively robust measure to examine the relative competitiveness between exchanges. Harris et al. (2002) points out that exchanges compete to attract informed traders based on the liquidity and efficiency of the market. The relative contribution to price discovery, in essence, offers a simple way of measuring the relative competiveness of the ASX and NZX. Our findings show that the NZX is losing ground to the ASX for firms that are cross-listed between the two exchanges. The long-term concern is that if this trend continues, it raises questions about the value of the listing on the NZX, not only for Australian but also for New Zealand firms.

\subsection{Determinants of Price Discovery}

The next question we address is what factors affect the relative contributions of price discovery. Understanding these factors may offer guidance to the areas in which exchanges should seek to improve their competitiveness. We examine the determinants of price discovery by employing pooled OLS regressions. We follow Eun and Sabherwal (2003) and take a logistic transformation of the NZX component share and information shares to ensure the values lie between 0 and 1 . We employ a dynamic model, where we include a lag of the price discovery measure. The dynamic model controls for the potential that price discovery is persistent over time, where the current value is driven in part by the previous year's value. 
The first set of determinants we employ relate to the location of trading and quoting activity. Eun and Sabherwal (2003) and Hasbrouck (1995) show that location of trading activity, especially volume traded, plays a significant role in determining price discovery. We consider three measures, relative trades, relative quotes and relative volume traded. All three measures are defined as the value for the ASX divided by the value for the NZX; for example relative trades is defined as the number of trades per day on the ASX divided by the number trades per day on the NZX. As such, a relative measure less than 1 would indicate that the NZX has the majority of the activity while greater than 1 would indicate otherwise.

In addition to the location of trading and quoting activity, we also consider the impact of transaction costs. Specifically, we consider the relative bid-ask spread, defined as the average percentage spread on the ASX divided by the average percentage spread on the NZX. For cross-listed securities, informed traders have a choice in which market they choose to exploit their information However, spreads, a cost for trading, imposes a cost on informed traders seeking to exploit their information. Given that the stocks in both markets are identical, an informed trader may choose to trade in the lowest cost market so as to maximise their profit. Harris et al. (2002) demonstrate that the NYSE's share of price discovery increased when its spreads relative to regional exchanges decline.

We further control for two other factors that are likely to influence the relative contributions of the NZX to price discovery. Specifically, we control for the log of the market value of the firm at the end of the year. It is likely that larger firms would find a more active market in a 
foreign market and that may influence the relative contributions to price discovery. We also control for time effect by including time dummies to control for any time variation/trends in the price discovery measures.

Table 5 presents the regression results for New Zealand and Australian firms, where we compute robust standard errors by controlling for clustering at the firm level. For the sample of New Zealand firms (Panel A), we observe a strong degree of persistence in the level of price discovery, as shown by the significant positive coefficients for the lag measure in our model. We also find a significant negative relationship with the NZX price discovery measure and Relative Trades. This negative relationship indicates that as the NZX's share of the number of trades grows, and so the relative trade measure gets smaller, the NZX's price discovery increases. We further note that Relative Spread is positive and significant in three out of four regressions, suggesting that increased spreads on the ASX, or decreased spreads on the NZX lead to a greater level of price discovery on the NZX. Finally, we find that Relative Volume becomes significant once we drop Relative Trades from the regressions.

In Panel B of Table 5, we report the regression results for the Australian firms. As with the New Zealand firms, we observe strong persistence in the level of the price discovery. In terms of the determinants of price discovery, the results are a bit weaker than for the New Zealand firms. We observe a positive and significant relationship between Relative Spread and CS suggesting that higher spreads on the ASX, or lower spreads on the NZX lead to an increase in the price discovery measures for the NZX. We also observe a negative and significant relationship between Relative Volume and IS, suggesting that if traded volume 
increases in the ASX, or decreases in the NZX, the NZX's contribution to price discovery decreases.

\section{Conclusion}

In this paper, we examine the contributions to price discovery for Australia/New Zealand cross-listed stocks. Using a sample for 11 New Zealand firms cross-listed on the ASX and 8 Australian firms cross-listed on the NZX, we compute yearly Component Shares and Information Shares over the period 1998-2012. Our results show that over this period of time there has been a marked decrease in the NZX's contribution to price discovery both for New Zealand and Australian firms. For New Zealand firms this decline goes from about $90 \%$ in 1998 to about $50 \%$ in 2012 . For Australian firms the decline goes from about $35 \%$ to $15 \%$, suggesting that for Australian firms the NZX is almost a pure satellite market. When we examine the determinants of price discovery, we find a strong relationship between relative trades, volume and spread for New Zealand firms. For Australian firms, relative spread and volume seem to be important determinants.

Overall, our findings suggest that improving the NZX's share of the trading in New Zealand companies is necessary to improve the price discovery of these companies and so reverse the

trend of declining price discovery. Likewise, efforts to reduce the relative spreads of Australian firms and increase the local share of trading and quoting activity may also allow the NZX to become more relevant to Australian firms and so attract more informed trading. 


\section{References}

Bacidore, J. and G. Sofianos (2002), "Liquidity Provision and Specialist Trading in NYSElisted non-U.S. Stocks.” Journal of Financial Economics 63, 133-158.

Ding, D., F. Harris, S. Lau, and T. McInish (1999), "An investigation of price discovery in informationally-linked markets: Equity trading in Malaysia and Singapore." Journal of Multinational Financial Management 9, 317-329.

Eun, C. S. and S. Sabherwal (2003), "Cross-Border Listing and Price Discovery: Evidence from US-Listed Canadian Stocks," Journal of Finance 58, 549-575.

Frijns, B., A. Gilbert and A. Tourani-Rad (2010), "The Dynamics of Price Discovery for Cross-listed Shares: Evidence from Australia and New Zealand." Journal of Banking and Finance 34, 498-508.

Gonzalo, J. and C. Granger (1995), "Estimation of common long-memory components in cointegrated systems."Journal of Business and Economic Statistics 13, 27-36.

Harris, F., T. McInish and R. Wood (2002), "Security Price Adjustment across Exchanges: An Investigation of Common Factor Components for Dow Stocks." Journal of Financial Markets 5, 341-348.

Hasbrouck, J. (1995), "One Security, Many Markets: Determining the Contributions to Price Discovery”, Journal of Finance 50, 1175-1199.

Hupperets, E., and A. Menkveld, (2002), "Intraday analysis of market integration: Dutch blue chips traded in Amsterdam and New York." Journal of Financial Markets 5, 57-82.

Kadapakkam, P., L. Misra, and Y. Tse (2003), "International price discovery for emerging stock markets: Evidence from Indian GDRs." Review of Quantitative Finance and Accounting 21, 179-199.

Lieberman, O., U. Ben-Zion, and S. Hauser (1999), "A characterization of the price behavior of international dual stocks: An error correction approach." Journal of International Money and Finance 18, 289-304.

Lok, E., and P. Kalev (2006), "The intraday price behavior of Australian and New Zealand cross-listed stocks." International Review of Financial Analysis 15, 377-397.

PR Newswire (1988), April 15.

Su, Q., Chong, T., 2007. Determining the contributions to price discovery for Chinese crosslisted stocks. Pacific-Basin Finance Journal 15, 140-153.

Wood, A. (1 September 2011). "Cavotech gets nod for Swedish Shift" available at http://www.stuff.co.nz/business/industries/5548042/Cavotec-gets-nod-for-Swedish-shift 
Table 1: Summary Statistics

\begin{tabular}{|c|c|c|c|c|c|c|c|c|c|c|c|c|}
\hline & \multicolumn{3}{|c|}{ Daily Trades } & \multicolumn{3}{|c|}{ Daily Quotes } & \multicolumn{3}{|c|}{ Daily Volume } & \multicolumn{3}{|c|}{ Bid-Ask Spread } \\
\hline & NZX & ASX & NZX/ASX & NZX & ASX & NZX/ASX & NZX & ASX & NZX/ASX & NZX & ASX & NZX/ASX \\
\hline \multicolumn{13}{|c|}{ Panel A: New Zealand Firms } \\
\hline AIA & 102.94 & 8.63 & 11.93 & 785.48 & 51.25 & 15.33 & $1,283,835$ & 43,289 & 29.66 & 0.5375 & 4.1345 & 0.13 \\
\hline AIR & 50.05 & 15.86 & 3.16 & 358.79 & 37.11 & 9.67 & 954,768 & 146,223 & 6.53 & 1.3002 & 2.4901 & 0.52 \\
\hline FBU & 146.70 & 293.10 & 0.50 & $1,346.88$ & 972.52 & 1.38 & $1,430,482$ & 282,854 & 5.06 & 0.3994 & 1.9247 & 0.21 \\
\hline FPH & 74.74 & 15.10 & 4.95 & 654.68 & 63.59 & 10.30 & 820,405 & 45,338 & 18.10 & 0.6381 & 2.3929 & 0.27 \\
\hline NPX & 45.25 & 10.19 & 4.44 & 498.68 & 39.37 & 12.67 & 245,233 & 35,043 & 7.00 & 0.8600 & 5.1975 & 0.17 \\
\hline $\mathrm{NZO}$ & 27.69 & 10.05 & 2.76 & 285.80 & 33.57 & 8.51 & 274,368 & 50,330 & 5.45 & 3.5392 & 5.0985 & 0.69 \\
\hline SKC & 95.50 & 28.39 & 3.36 & 711.25 & 124.17 & 5.73 & 966,278 & 70,581 & 13.69 & 0.5055 & 3.7607 & 0.13 \\
\hline SKT & 46.67 & 4.73 & 9.87 & 517.80 & 50.64 & 10.23 & 406,663 & 31,985 & 12.71 & 0.8084 & 6.7679 & 0.12 \\
\hline TEL & 227.80 & 414.99 & 0.55 & $1,373.01$ & $1,184.54$ & 1.16 & $8,171,828$ & $2,091,375$ & 3.91 & 0.3475 & 0.7699 & 0.45 \\
\hline TWR & 47.34 & 57.45 & 0.82 & 305.91 & 149.56 & 2.05 & 487,647 & 236,470 & 2.06 & 0.9135 & 1.7517 & 0.52 \\
\hline WHS & 63 & 5.09 & 12.38 & $3,11.511$ & 26.22 & 11.88 & 404,602 & 11,001 & 36.78 & 0.6063 & 4.0977 & 0.15 \\
\hline Average & 84.33 & 78.51 & 4.97 & 649.98 & 248.41 & 8.08 & $1,404,191$ & 276,771 & 12.81 & 0.95 & 3.49 & 0.31 \\
\hline \multicolumn{13}{|c|}{ Panel B: Australian Firms } \\
\hline AMP & 57.98 & 1972.08 & 0.03 & 395.13 & $4,700.79$ & 0.08 & 139,178 & $4,915,832$ & 0.03 & 1.4558 & 0.4690 & 3.10 \\
\hline ANZ & 2168.09 & 4077.89 & 0.53 & $6,347.43$ & $1,1125.7$ & 0.57 & $2,363,268$ & $4,366,166$ & 0.54 & 1.5019 & 0.2504 & 6.00 \\
\hline APN & 2.32 & 632.46 & 0.00 & 248.62 & $2,064.95$ & 0.12 & 95,007 & $1,070,037$ & 0.09 & 7.9423 & 1.0425 & 7.62 \\
\hline GFF & 11.08 & 1164.19 & 0.01 & 238.04 & $3,603.44$ & 0.07 & 287,871 & $5,243,690$ & 0.05 & 2.5251 & 0.6182 & 4.08 \\
\hline PPP & 6.14 & 28.26 & 0.22 & 111.51 & 71.41 & 1.56 & 195,647 & 539,558 & 0.36 & 5.1579 & 3.5145 & 1.47 \\
\hline TLS & 16.85 & 2597.92 & 0.01 & 229.26 & $5,568.73$ & 0.04 & 403,923 & $24,964,134$ & 0.02 & 1.4393 & 0.4995 & 2.88 \\
\hline WBC & 18.92 & 6696.66 & 0.00 & $1,240.03$ & $1,9674.5$ & 0.06 & 188,637 & $5,536,412$ & 0.03 & 1.7711 & 0.1834 & 9.66 \\
\hline LNN & 15 & 408.82 & 0.04 & 312.79 & $1,191.82$ & 0.26 & 448,735 & 732,680 & 0.61 & 2.1592 & 1.1948 & 1.81 \\
\hline Average & 287.05 & 2197.29 & 0.10 & $1,140.35$ & $6,000.17$ & 0.35 & 515,283 & $5,921,063$ & 0.22 & 2.99 & 0.97 & 4.58 \\
\hline
\end{tabular}

This table reports summary statistics for the full sample period, January 1998 to December 2012. Daily Trades is the average number of trades per day, Daily Quotes is the average number of new quotes per day, Daily Volume is the average number of shares traded per day and Bid-Ask Spread is the average percentage bid ask spread measured as the difference between the bid and the ask price divided by the midpoint each minute while the respective market is open. 
Table 2: Summary Statistics by Per Year Average

\begin{tabular}{|c|c|c|c|c|c|c|c|c|c|c|c|c|}
\hline & \multicolumn{3}{|c|}{ Daily Trades } & \multicolumn{3}{|c|}{ Daily Quotes } & \multicolumn{3}{|c|}{ Daily Volume } & \multicolumn{3}{|c|}{ Bid-Ask Spread } \\
\hline & NZX & ASX & NZX/ASX & $\mathrm{NZX}$ & ASX & NZX/ASX & NZX & ASX & NZX/ASX & NZX & ASX & NZX/ASX \\
\hline \multicolumn{13}{|c|}{ Panel A: New Zealand Firms } \\
\hline 1998 & 68.84 & 2.24 & 30.73 & 50.24 & 15.22 & 3.30 & $1,591,501$ & 25,459 & 62.51 & 3.88 & 7.43 & 0.52 \\
\hline 1999 & 111.93 & 31.39 & 3.57 & 58.01 & 49.43 & 1.17 & $1,626,778$ & 110,587 & 14.71 & 2.30 & 3.49 & 0.66 \\
\hline 2000 & 81.46 & 30.85 & 2.64 & 46.53 & 48.89 & 0.95 & $1,219,730$ & 116,296 & 10.49 & 1.73 & 6.89 & 0.25 \\
\hline 2001 & 84.16 & 27.59 & 3.05 & 53.77 & 50.85 & 1.06 & 981,253 & 134,473 & 7.30 & 1.17 & 4.32 & 0.27 \\
\hline 2002 & 78.19 & 21.00 & 3.72 & 69.04 & 49.67 & 1.39 & $1,142,071$ & 163,208 & 7.00 & 1.27 & 3.54 & 0.36 \\
\hline 2003 & 81.35 & 23.56 & 3.45 & 87.77 & 58.74 & 1.49 & $1,194,510$ & 216,109 & 5.53 & 1.21 & 3.11 & 0.39 \\
\hline 2004 & 67.76 & 27.13 & 2.50 & 81.26 & 61.67 & 1.32 & $1,382,105$ & 243,516 & 5.68 & 0.79 & 1.87 & 0.42 \\
\hline 2005 & 79.86 & 35.90 & 2.22 & 771.07 & 101.69 & 7.58 & $1,355,959$ & 236,570 & 5.73 & 0.78 & 2.01 & 0.39 \\
\hline 2006 & 78.21 & 51.29 & 1.52 & 982.18 & 152.88 & 6.42 & $1,970,764$ & 362,265 & 5.44 & 0.79 & 2.26 & 0.35 \\
\hline 2007 & 83.14 & 70.07 & 1.19 & 711.31 & 219.91 & 3.23 & $1,827,356$ & 318,412 & 5.74 & 0.73 & 3.22 & 0.23 \\
\hline 2008 & 88.85 & 90.30 & 0.98 & 917.66 & 298.64 & 3.07 & $1,855,738$ & 390,599 & 4.75 & 1.07 & 5.58 & 0.19 \\
\hline 2009 & 84.31 & 133.36 & 0.63 & 935.06 & 440.37 & 2.12 & $1,872,944$ & 395,701 & 4.73 & 0.95 & 4.07 & 0.23 \\
\hline 2010 & 79.11 & 138.90 & 0.57 & 864.60 & 478.10 & 1.81 & $1,676,703$ & 453,627 & 3.70 & 0.66 & 1.79 & 0.37 \\
\hline 2011 & 128.86 & 226.77 & 0.57 & $1,385.32$ & 731.62 & 1.89 & $2,030,003$ & 631,104 & 3.22 & 0.72 & 2.05 & 0.35 \\
\hline 2012 & 137.27 & 220.22 & 0.62 & $1,493.53$ & 700.40 & 2.13 & $1,959,430$ & 453,727 & 4.32 & 0.73 & 2.57 & 0.28 \\
\hline \multicolumn{13}{|c|}{ Panel B: Australian Firms } \\
\hline 1998 & 266.14 & 868.09 & 0.31 & 196.93 & 969.58 & 0.20 & $1,168,685$ & $3,308,830$ & 0.35 & 0.89 & 0.71 & 1.25 \\
\hline 1999 & 145.45 & 702.08 & 0.21 & 142.85 & 764.80 & 0.19 & 604,047 & $2,335,937$ & 0.26 & 0.95 & 0.63 & 1.51 \\
\hline 2000 & 119.01 & 708.57 & 0.17 & 122.01 & 714.06 & 0.17 & 641,544 & $3,129,549$ & 0.20 & 1.00 & 0.89 & 1.12 \\
\hline 2001 & 130.81 & 888.14 & 0.15 & 162.07 & 860.71 & 0.19 & 636,053 & $4,917,110$ & 0.13 & 0.97 & 0.56 & 1.73 \\
\hline 2002 & 149.66 & 902.81 & 0.17 & 237.44 & $1,222.89$ & 0.19 & 601,060 & $6,388,217$ & 0.09 & 1.05 & 0.51 & 2.06 \\
\hline 2003 & 152.29 & 867.34 & 0.18 & 252.47 & $1,229.75$ & 0.21 & 531,397 & $5,634,382$ & 0.09 & 2.64 & 2.08 & 1.27 \\
\hline 2004 & 104.88 & 623.41 & 0.17 & 185.93 & 918.43 & 0.20 & 352,643 & $4,131,812$ & 0.09 & 2.12 & 1.24 & 1.71 \\
\hline 2005 & 117.08 & 864.19 & 0.14 & $1,178.84$ & $1,363.64$ & 0.86 & 746,110 & $8,571,842$ & 0.09 & 2.24 & 0.99 & 2.26 \\
\hline 2006 & 155.92 & 1057.14 & 0.15 & $1,880.98$ & $1,852.57$ & 1.02 & 347,381 & $6,034,475$ & 0.06 & 2.24 & 0.86 & 2.60 \\
\hline 2007 & 251.92 & 1590.99 & 0.16 & 707.60 & $3,589.86$ & 0.20 & 425,187 & $5,535,464$ & 0.08 & 2.88 & 0.73 & 3.95 \\
\hline 2008 & 523.75 & 3268.12 & 0.16 & $1,869.24$ & $8,289.97$ & 0.23 & 718,405 & $8,119,263$ & 0.09 & 5.07 & 1.16 & 4.37 \\
\hline 2009 & 568.92 & 3539.64 & 0.16 & $1,704.07$ & $10,271.27$ & 0.17 & 766,810 & $9,124,730$ & 0.08 & 4.23 & 0.89 & 4.75 \\
\hline 2010 & 742.81 & 4202.09 & 0.18 & $2,597.85$ & $13,386.47$ & 0.19 & 723,314 & $9,890,798$ & 0.07 & 3.46 & 0.59 & 5.86 \\
\hline 2011 & 842.82 & 4840.53 & 0.17 & $3,178.07$ & $16,409.22$ & 0.19 & 801,083 & $10,607,005$ & 0.08 & 3.66 & 0.76 & 4.82 \\
\hline 2012 & 807.72 & 4510.94 & 0.18 & $2,605.41$ & $13,307.73$ & 0.20 & 660,371 & $8,564,564$ & 0.08 & 2.99 & 0.85 & 3.52 \\
\hline
\end{tabular}


This table reports summary statistics for the full sample period, January 1998 to December 2012, averaged by home country. Daily Trades is the average number of trades per day, Daily Quotes is the average number of new quotes per day, Daily Volume is the average number of shares traded per day and Bid-Ask Spread is the average percentage bid ask spread measured as the difference between the bid and the ask price divided by the midpoint each minute while the respective market is open. 
Table 3: Price Discovery Measures per Firm

\begin{tabular}{|c|c|c|c|c|c|c|c|c|}
\hline \multicolumn{4}{|c|}{ NZX } & \multicolumn{3}{|c|}{ ASX } & \multirow{3}{*}{$\mathrm{CS}^{\mathrm{NZX}}$} & \multirow{3}{*}{$\mathrm{CS}^{\mathrm{ASX}}$} \\
\hline & IS & IS & IS & IS & IS & IS & & \\
\hline & Upper & Lower & Midpoint & Upper & Lower & Midpoint & & \\
\hline \multicolumn{9}{|c|}{ Panel A: New Zealand Domiciled Firms } \\
\hline AIA & 72.60 & 68.52 & 70.56 & 31.48 & 27.40 & 29.44 & 68.55 & 31.45 \\
\hline AIR & 65.23 & 60.33 & 62.78 & 39.67 & 34.77 & 37.22 & 59.80 & 40.20 \\
\hline FBU & 66.64 & 60.97 & 63.80 & 39.03 & 33.36 & 36.20 & 66.34 & 33.66 \\
\hline FPH & 73.86 & 63.45 & 68.65 & 36.55 & 26.14 & 31.35 & 69.50 & 30.50 \\
\hline NPX & 76.89 & 61.47 & 69.18 & 38.53 & 23.11 & 30.82 & 72.32 & 27.68 \\
\hline $\mathrm{NZO}$ & 77.95 & 77.10 & 77.53 & 22.90 & 22.05 & 22.47 & 74.61 & 25.39 \\
\hline SKC & 76.74 & 64.09 & 70.42 & 35.91 & 23.26 & 29.58 & 72.21 & 27.79 \\
\hline SKT & 82.90 & 66.60 & 74.75 & 33.40 & 17.10 & 25.25 & 77.03 & 22.97 \\
\hline TEL & 61.00 & 52.88 & 56.94 & 47.12 & 39.00 & 43.06 & 55.10 & 44.90 \\
\hline TWR & 65.85 & 61.15 & 63.50 & 38.85 & 34.15 & 36.50 & 67.04 & 32.96 \\
\hline WHS & 89.63 & 79.88 & 84.76 & 20.12 & 10.37 & 15.24 & 83.33 & 16.67 \\
\hline Average & 73.57 & 65.13 & 69.35 & 34.87 & 26.43 & 30.65 & 69.62 & 30.38 \\
\hline \multicolumn{9}{|c|}{ Panel B: Australian Domiciled Firms } \\
\hline AMP & 14.52 & 2.73 & 8.62 & 97.27 & 85.48 & 91.38 & 10.04 & 89.96 \\
\hline ANZ & 35.39 & 3.08 & 19.23 & 96.92 & 64.61 & 80.77 & 15.00 & 85.00 \\
\hline APN & 25.26 & 13.21 & 19.24 & 86.79 & 74.74 & 80.76 & 27.11 & 72.89 \\
\hline GFF & 13.41 & 11.10 & 12.26 & 88.90 & 86.59 & 87.74 & 16.12 & 83.88 \\
\hline PPP & 37.43 & 36.81 & 37.12 & 63.19 & 62.57 & 62.88 & 48.01 & 51.99 \\
\hline TLS & 9.16 & 5.80 & 7.48 & 94.20 & 90.84 & 92.52 & 11.23 & 88.77 \\
\hline WBC & 33.52 & 0.99 & 17.25 & 99.01 & 66.48 & 82.75 & 6.90 & 93.10 \\
\hline LNN & 38.52 & 23.61 & 31.07 & 76.39 & 61.48 & 68.93 & 36.81 & 63.19 \\
\hline Average & 25.90 & 12.17 & 19.03 & 87.83 & 74.10 & 80.97 & 21.40 & 78.60 \\
\hline
\end{tabular}

We report the average of the per year estimates of the two price discovery measures. 
Table 4: Per Year New Zealand Component Share Estimates

\begin{tabular}{|c|c|c|c|c|c|c|c|c|c|c|c|c|c|c|c|}
\hline & 1998 & 1999 & 2000 & 2001 & 2002 & 2003 & 2004 & 2005 & 2006 & 2007 & 2008 & 2009 & 2010 & 2011 & 2012 \\
\hline \multicolumn{16}{|c|}{ Panel A: New Zealand Domiciled Firms } \\
\hline AIA & & & 82.46 & 89.07 & 86.85 & 94.18 & 83.75 & 73.00 & 68.87 & 79.95 & 72.17 & 57.99 & 42.87 & 27.50 & 32.55 \\
\hline AIR & & & & 45.73 & 56.61 & 59.04 & 52.06 & 63.26 & 58.37 & 63.61 & 70.01 & 79.17 & 63.04 & 53.75 & 52.98 \\
\hline FBU & & & & 86.88 & 96.48 & 81.86 & 83.34 & 75.55 & 71.71 & 70.60 & 65.58 & 63.17 & 53.19 & 27.06 & 20.65 \\
\hline FPH & & & & 64.62 & 73.38 & 61.83 & 72.48 & 83.82 & 78.64 & 80.14 & 73.90 & 69.27 & 66.13 & 54.67 & 55.19 \\
\hline NPX & & & & & & & 92.87 & 76.85 & 79.26 & 66.96 & 79.51 & 56.47 & 66.30 & 68.76 & 63.86 \\
\hline NZO & 88.43 & 75.73 & 80.53 & 80.55 & 79.05 & 66.08 & 74.48 & 84.40 & 76.44 & 69.56 & 78.37 & 73.24 & 58.34 & 65.32 & 68.58 \\
\hline SKC & & & 63.80 & 64.85 & 91.96 & 99.31 & 86.16 & 81.77 & 79.40 & 83.89 & 74.31 & 74.70 & 44.38 & 37.15 & 57.11 \\
\hline SKT & & & & & & & & & 77.49 & 77.97 & 85.71 & 86.79 & 78.81 & 64.33 & 68.13 \\
\hline TEL & 86.91 & 85.18 & 79.17 & 75.30 & 73.19 & 70.86 & 62.05 & 68.36 & 63.98 & 45.97 & 28.43 & 18.43 & 3.15 & 20.29 & 9.23 \\
\hline TWR & & 78.42 & 73.07 & 71.52 & 81.10 & 66.95 & 63.68 & 61.74 & 42.90 & 46.56 & 71.78 & 74.03 & 70.70 & 71.15 & 64.91 \\
\hline WHS & & & & 90.37 & 87.05 & 89.34 & 83.30 & 83.26 & 76.23 & 81.22 & 75.90 & & & & \\
\hline \multicolumn{16}{|c|}{ Panel B: Australian Domiciled Firms } \\
\hline AMP & 37.64 & 19.01 & 22.13 & 19.20 & 16.67 & 3.71 & 11.11 & 2.31 & 4.83 & 1.18 & 7.53 & 0.28 & 0.98 & 4.29 & 2.70 \\
\hline ANZ & 18.49 & 22.22 & 26.07 & 24.99 & 25.90 & 15.88 & 9.78 & 19.08 & 14.25 & 9.37 & 10.17 & 3.65 & 11.48 & 6.30 & 7.44 \\
\hline APN & & & & & & & 31.22 & 27.93 & 26.58 & 54.43 & 51.83 & 14.82 & 13.60 & 19.20 & 4.34 \\
\hline GFF & & & & & & & & 79.67 & 15.48 & 11.44 & 5.75 & 15.75 & 22.44 & 11.17 & 9.29 \\
\hline PPP & & & & & & 48.34 & 56.39 & 50.44 & 51.26 & 46.06 & 41.22 & 37.46 & 33.04 & 55.72 & 60.18 \\
\hline TLS & 11.97 & 4.97 & 4.96 & 1.68 & 9.35 & 9.16 & 22.53 & 12.17 & 11.21 & 4.57 & 1.75 & 0.27 & 44.31 & 43.14 & 5.08 \\
\hline WBC & & & & & & & & 13.62 & 11.39 & 15.83 & 0.16 & 3.73 & 2.66 & 0.88 & 6.94 \\
\hline LNN & 74.76 & 80.48 & 67.48 & 44.03 & 31.99 & 22.28 & 11.98 & 13.58 & 23.15 & 18.12 & 19.43 & 34.40 & & & \\
\hline
\end{tabular}


Table 5: Price Discovery Determinants Regressions

\begin{tabular}{|c|c|c|c|c|}
\hline \multicolumn{5}{|c|}{ Panel A: New Zealand Firms } \\
\hline & \multicolumn{2}{|c|}{ Component Share } & \multicolumn{2}{|c|}{ Info Share } \\
\hline Lag Dep. & $\begin{array}{c}0.485 * * * \\
(7.13)\end{array}$ & $\begin{array}{c}0.568 * * * \\
(5.78)\end{array}$ & $\begin{array}{c}0.458 * * * \\
(5.57)\end{array}$ & $\begin{array}{c}0.583 * * * \\
(5.95)\end{array}$ \\
\hline Rel Trades & $\begin{array}{c}-0.343 * * \\
(-2.37)\end{array}$ & & $\begin{array}{c}-0.530 * * \\
(-2.88)\end{array}$ & \\
\hline Rel Quotes & $\begin{array}{l}0.150 \\
(1.13)\end{array}$ & $\begin{array}{l}0.156 \\
(1.10)\end{array}$ & $\begin{array}{l}0.245 \\
(1.33)\end{array}$ & $\begin{array}{l}0.205 \\
(1.27)\end{array}$ \\
\hline Rel Volume & $\begin{array}{l}0.288 \\
(0.61)\end{array}$ & $\begin{array}{c}-1.01 * * \\
(-2.05)\end{array}$ & $\begin{array}{l}-0.070 \\
(-0.15)\end{array}$ & $\begin{array}{c}-1.899 * * \\
(-2.77)\end{array}$ \\
\hline Rel Spread & $\begin{array}{c}0.075 * * \\
(2.75)\end{array}$ & $\begin{array}{c}0.078 * * \\
(2.90)\end{array}$ & $\begin{array}{l}0.049 \\
(1.67)\end{array}$ & $\begin{array}{l}0.057 * \\
(1.81)\end{array}$ \\
\hline Market Value & $\begin{array}{l}-0.046 \\
(-0.60)\end{array}$ & $\begin{array}{c}-0.141^{* *} \\
(-2.53)\end{array}$ & $\begin{array}{l}-0.001 \\
(-0.01)\end{array}$ & $\begin{array}{l}-0.152 \\
(-1.74)\end{array}$ \\
\hline Year Dummies & YES & YES & YES & YES \\
\hline Observations & 119 & 119 & 119 & 119 \\
\hline R-squared & 0.785 & 0.761 & 0.694 & 0.661 \\
\hline \multicolumn{5}{|c|}{ Panel B: Australian Firms } \\
\hline & \multicolumn{2}{|c|}{ Component Share } & \multicolumn{2}{|c|}{ Info Share } \\
\hline Lag Dep. & $\begin{array}{c}0.307 * * \\
(2.34)\end{array}$ & $\begin{array}{c}0.307 * * \\
(2.37)\end{array}$ & $\begin{array}{c}0.606 * * * \\
(6.12)\end{array}$ & $\begin{array}{c}0.621 * * * * \\
(5.76)\end{array}$ \\
\hline Rel Trades & $\begin{array}{c}0.00 \\
(0.00)\end{array}$ & & $\begin{array}{l}0.002 \\
(0.89)\end{array}$ & \\
\hline Rel Quotes & $\begin{array}{l}-0.008 \\
(-1.01)\end{array}$ & $\begin{array}{c}-0.008 * \\
(-2.17)\end{array}$ & $\begin{array}{l}-0.017 * \\
(-1.94)\end{array}$ & $\begin{array}{c}-0.010^{*} \\
(-2.25)\end{array}$ \\
\hline Rel Volume & $\begin{array}{l}-0.005 \\
(-0.71)\end{array}$ & $\begin{array}{l}-0.005 \\
(-0.72)\end{array}$ & $\begin{array}{c}-0.008^{*} \\
(-2.00)\end{array}$ & $\begin{array}{c}-0.005^{* *} \\
(-2.42)\end{array}$ \\
\hline Rel Spread & $\begin{array}{c}0.419 * * * \\
(3.85)\end{array}$ & $\begin{array}{l}0.419 * \\
(2.01)\end{array}$ & $\begin{array}{l}0.050 \\
(0.37)\end{array}$ & $\begin{array}{l}-0.082 \\
(-0.97)\end{array}$ \\
\hline Market Value & $\begin{array}{l}-0.172 \\
(-1.83)\end{array}$ & $\begin{array}{l}-0.172 * \\
(-2.23)\end{array}$ & $\begin{array}{l}-0.024 \\
(-0.25)\end{array}$ & $\begin{array}{l}-0.047 \\
(-0.59)\end{array}$ \\
\hline Year Dummies & YES & YES & YES & YES \\
\hline Observations & 84 & 84 & 84 & 84 \\
\hline R-squared & 0.632 & 0.632 & 0.587 & 0.583 \\
\hline
\end{tabular}


Figure 1: NZX Price Discover over Time

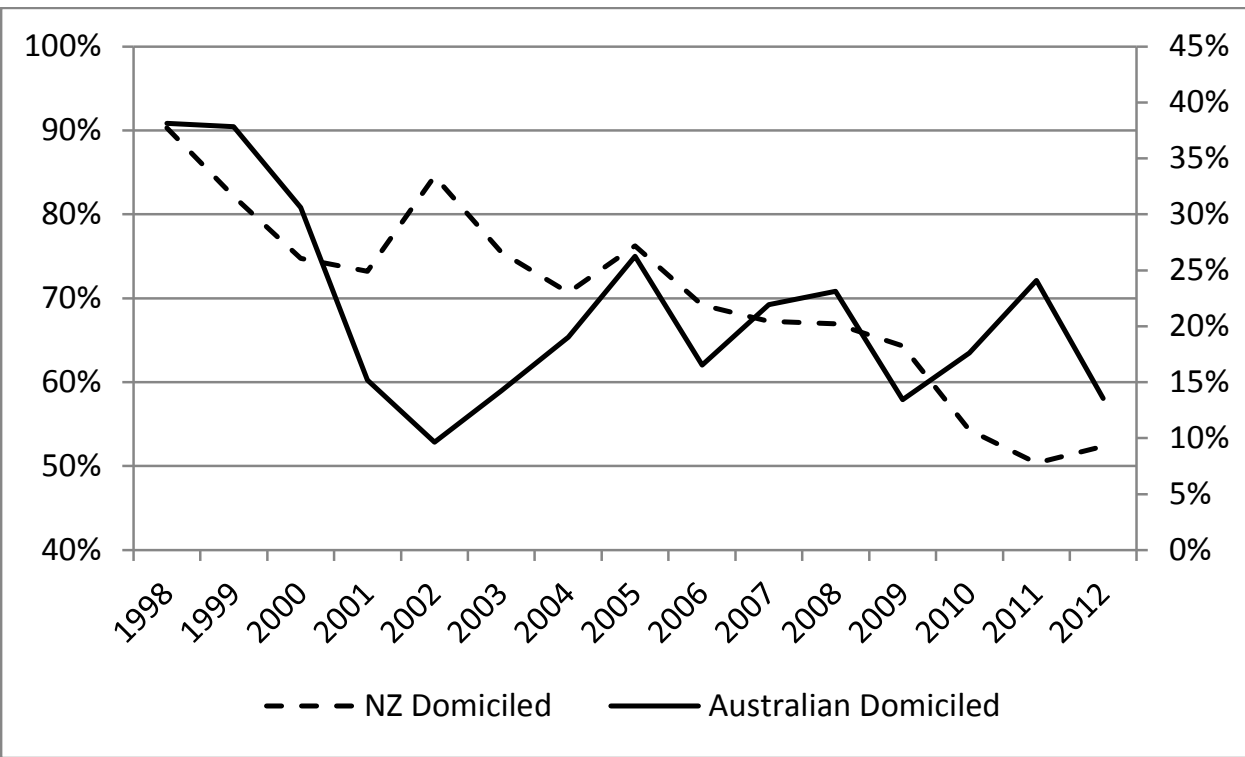

Panel A: Information Shares

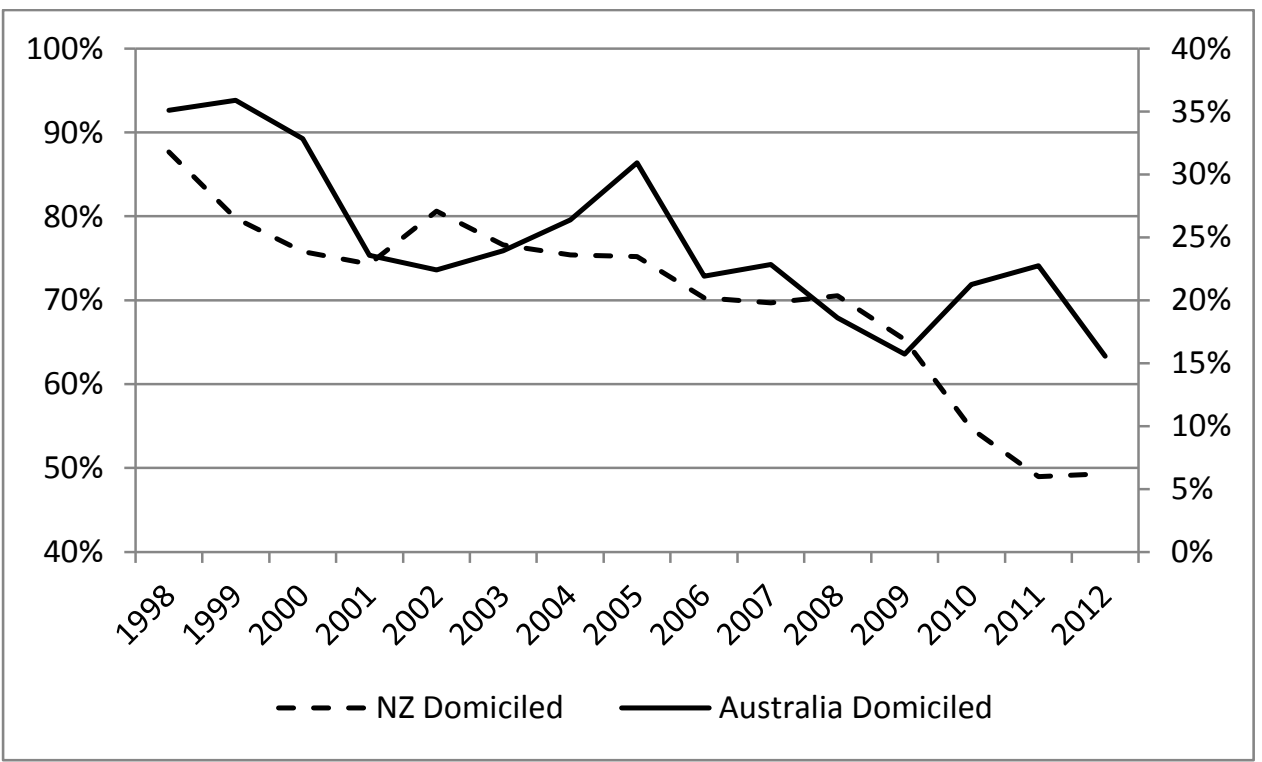

Panel B: Component Shares 